\title{
Examining the relationship between cardiac troponin $T$ and cardiac morphology, function, and fibrosis - a cardiac magnetic resonance study
}

Mohamad G Ghosn ${ }^{3}$, Stephen Pickett ${ }^{1}$, Patrick W Green ${ }^{1}$, Eric Y Yang ${ }^{2}$, Vijay Nambi ${ }^{2}$, Christie M Ballantyne ${ }^{2}$, Dipan J Shah ${ }^{3}$

From 18th Annual SCMR Scientific Sessions

Nice, France. 4-7 February 2015

\section{Background}

Elevated high sensitivity cardiac troponin (cTnT) levels, LVEF, and the degree of myocardial replacement fibrosis (RF) have been shown to be significantly associated with cardiovascular outcomes. However, the relationship amongst them has yet to be studied. Cardiac magnetic resonance (CMR) has become the gold standard for viability imaging and accurately characterizing RF. Recently, a new technique has been employed to quantify diffuse myocardial fibrosis via assessment of myocardial extracellular volume (ECV). The current study sought to investigate the association between ECV, RF, LVEF, LV mass (LVM) and cTnT levels.
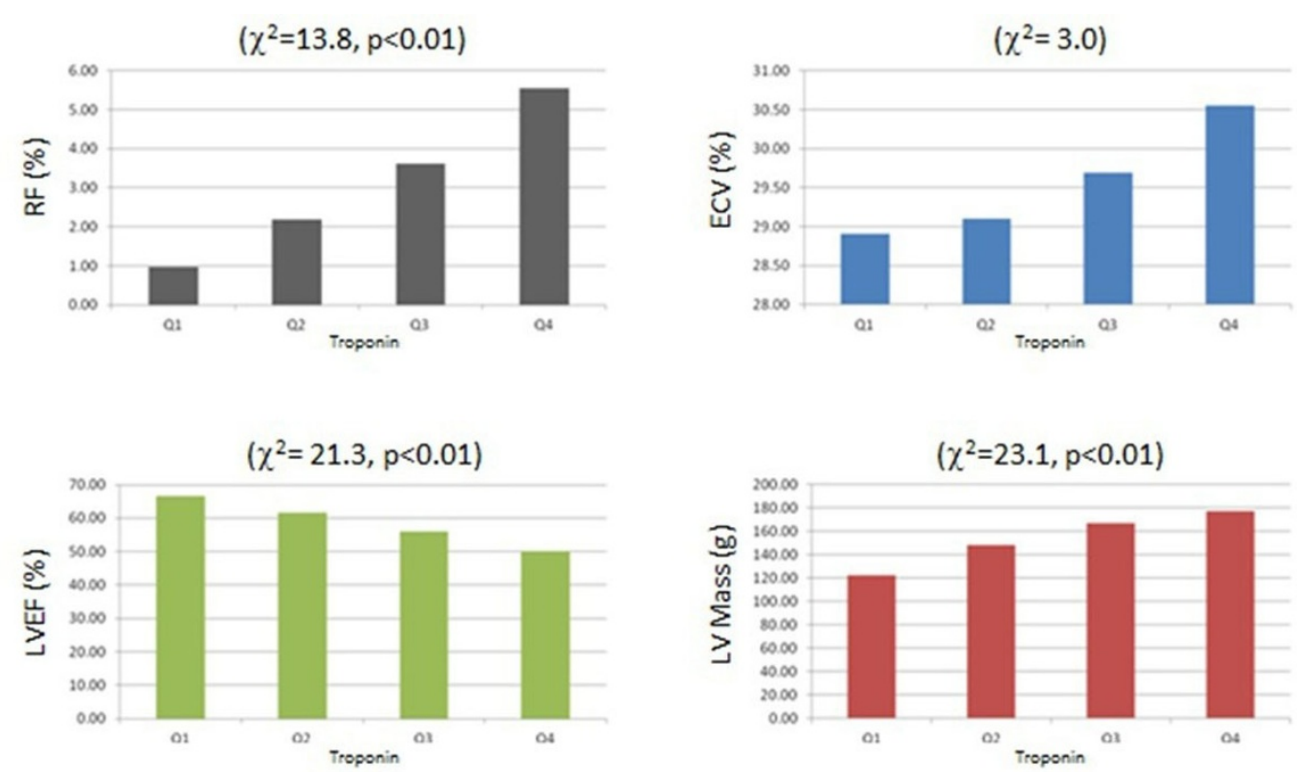

Figure 1 The LV mass and the percentages of RF, ECV, and LVEF according to the Quartile cardiac Troponin (cTnT) Levels.

${ }^{3}$ Cardiology, Houston Methodist DeBakey Heart \& Vascular Center, Houston,

TX, USA

Full list of author information is available at the end of the article

(c) 2015 Ghosn et al; licensee BioMed Central Ltd. This is an Open Access article distributed under the terms of the Creative Commons 


\section{Methods}

We enrolled 192 patients who underwent cine CMR for assessment of LVM and LVEF, delay enhancement CMR (DE-CMR) for assessment of RF, and T1 mapping for assessment of diffuse interstitial fibrosis (ECV). Patients with hypertrophic cardiomyopathy were excluded. Serum samples collected at time of scan were assayed for cTnT levels. The extent of RF was determined by visual inspection. ECV was estimated from the concentration of extracellular contrast agent in the myocardium relative to the blood in the dynamic steady state. Care was taken to avoid measuring ECV in regions with RF detected on DE-CMR.

\section{Results}

Mean age of enrolled patients was $62 \pm 14$ years $(59 \%$ males) with an average LVEF of $58 \pm 16 \%$. RF in the LV myocardium was present in 84 patients $(41 \%)$. The mean cTnT value was $27 \mathrm{ng} / \mathrm{L}$ and the median (interquartile range; IQR) was $11 \mathrm{ng} / \mathrm{L}$ (6 ng/L, $20 \mathrm{ng} / \mathrm{L})$. Using Kruskal-Wallis test with TnT quartiles as cuttoffs, ECV showed a non-significant positive relationship with increased levels of Troponin $\left(\mathrm{X}^{2}=3.0\right)$. With the same statistical test, the following parameters showed a very significant relationship: $\mathrm{RF}\left(\mathrm{X}^{2}=13.8, \mathrm{p}<0.01\right)$, LVEF $\left(\mathrm{X}^{2}=21.3, \mathrm{p}<0.01\right), \mathrm{LV}$ end diastolic volume $\left(\mathrm{X}^{2}=10.5\right.$, $\mathrm{p}=0.01)$, LV mass $\left(\mathrm{X}^{2}=23.1, \mathrm{p}<0.01\right)$.

\section{Conclusions}

This study demonstrates a significant mean rank between RF, LVEF, and LVM with cTnT levels. It also shows a positive relationship between ECV and cTnT. However, a larger study is needed to elucidate the true relationship between ECV and cTnT.

\section{Funding}

N/A.

\section{Authors' details}

'Baylor College of Medicine, Houston, TX, USA. 'Cardiology, Baylor College of Medicine, Houston, TX, USA. ${ }^{3}$ Cardiology, Houston Methodist DeBakey Heart \& Vascular Center, Houston, TX, USA.

Published: 3 February 2015

\section{doi:10.1186/1532-429X-17-S1-Q116}

Cite this article as: Ghosn et al:: Examining the relationship between cardiac troponin T and cardiac morphology, function, and fibrosis - a cardiac magnetic resonance study. Journal of Cardiovascular Magnetic Resonance 2015 17(Suppl 1):Q116.
Submit your next manuscript to BioMed Central and take full advantage of:

- Convenient online submission

- Thorough peer review

- No space constraints or color figure charges

- Immediate publication on acceptance

- Inclusion in PubMed, CAS, Scopus and Google Scholar

- Research which is freely available for redistribution

Submit your manuscript at www.biomedcentral.com/submit
C Biomed Central 